THURSDAY, DECEMBER 6, 1917.

\section{THE CO-ORDINATION OF RESEARCH.}

$\mathrm{T}^{\mathrm{T}}$ is often said in political circles that the way to shelve a subject is to appoint a Royal Commission upon it. The Commissioners collect a large amount of evidence and present a report, but usually the matter ends with the publication of the Blue Book, and nothing is done to carry the recommendations into effect. The Royal Commission on Scientific Instruction appointed in 1870 is an example of this kind. The whole of the scientific instruction given in the United Kingdom from the elementary schools to the universities, and including the museums and scientific work recognised by Government, is surveyed in the report of this Commission, issued in ten parts from 1871 to 1895 ; and the nation has suffered incalculable loss by not giving heed to its recommendations.

We wonder whether the deliberations and reports of the numerous Committees appointed since the opening of the war to deal with scientific subjects will meet with a like fate; and we anxiously await a sign that the Ministry of Reconstruction intends to produce from the information with which it will be provided a coherent and ordered scheme of national development. Lack of the spirit of organisation and system in both industrial and educational matters has prevented us from taking the lead even when we possessed the necessary knowledge and men to do so. Little has yet been done to show that the Government realises its responsibility for united effort in scientific and industrial advance, and for correlating the work of its various advisory Committees.

We are reminded of this deficiency by a question put by Sir Philip Magnus to the Secretary of State for the Colonies. Sir Philip Magnus asked

" whether any efficient system of co-ordinating the research work now being conducted in the laboratories of our universities, in the National Physical Laboratory, and in the Imperial Institute is being or has been arranged, more especially with the view of bringing the results of such researches into close relation with fresh problems connected with our Colonial trade and with our productive industries in this country and in our Dominions overseas; and whether opportunities are afforded for placing at the service of our manufacturers scientific experts to advise them or to conduct in their factories special investigations; and, if so, under what conditions."

The reply given in the House of Commons on November 29 was as follows:-

"The important questions raised by the hon. member are too large for effective treatment by No. 25 IO, VOL. IOO] way of question and answer, but, as he is no doubt aware, the Committee of the Privy Council for Scientific and Industrial Research are in the course of their administration collecting information as to research being conducted in various places and different types of institution which cannot but facilitate the co-ordination of research work which the hon. member desires. Moreover, as he will have gathered from the annual reports of that department, similar organisations have come, or are coming, into existence in other parts of the Empire, which are in close relation with the Research Department in this country. As an example of what is being done in the Oversea Dominions, I would refer the hon. member to the report of the Commonwealth Advisory Council of Science and Industry and the recently published South African Journal of Industries, which may be seen in the Colonial Office library. This Imperial machinery will enable those who are engared in our Colonial trade and in our productive industries to become acquainted with the problems arising in different parts of the Empire, and with the results of any researches now in progress either here or in the Dominions. The hon. member will be aware of the work of the Imperial Institute, which is always willing to put its expert advice at the disposal of manufacturers. As regards the final part of the question, the establishment of research associations, which is one of the main objects of the Research Department, is intended to place at the service of our manufacturers scientific experts who may advise them or conduct in their factories special investigations."

It cannot be said that the information provided in answer to Sir Philip Magnus's question throws much light upon the main subject of co-ordination of research work; it is merely a statement that various bodies are now concerned with research, but as to how far they are organised with common objects, or are co-operative, little is said. What we should like to know is whether the various Committees which have been appointed to deal with national and Imperial matters of scientific importance are working independently and whether their reports. published or in preparation are being brought together to produce an organic scheme assigning definite work to different departments. We have not much faith in the influence of the recommendations of these Committees unless a directorate exists to survey them as a whole and to show how they can be carried into effect without overlapping. Either the Ministry of Reconstruction or the Department of Scientific and Industrial Research might fulfil this function, but, so far as we know, neither is doing it. There should be a single bureau of scientific intelligence, where any manufacturer or industrial research worker may obtain information as to the position of published knowledge upon the particular subject in which he is interested and the laboratories 
where the subject can be further investigated if necessary. In some large industrial works the head of any department can obtain such information through the works library in which a staff exists to supply it. Something of the same kind is wanted on a national basis; and the most useful purpose the Department of Scientific and Industrial Research could perform would be to institute such a central bureau.

The institution of a great clearing-house for scientific facts and industrial needs would he of supreme value to national development. Intitnate connection must be established between workers in the fields of science and industry in order to bridge the gap which exists between scientific investigation and industrial application; and a sure way of accomplishing this is through an efficient and easily accessible intelligence bureau. It is to what has been termed the science of the use of science that the Germans owe to a great extent the place they have attained in the industrial world, though they have often employed unscrupulous means to reach their end. Every large industrial concern should have its own information and records department, which should be planned on the same lines as the central bureau. A few months ago M. Paul Otlet, director of the International Institute of Bibliography at Brussels, published in the Bulletin of the French Société d'Encouragement pour 1'Industrie nationale a scheme for an international bureau of this kind having as its functions the collection, classification, and dissemination of all information available which will tend to facilitate or develop industry. Without waiting for this scheme to be established, a beginning should be made with a national clearing-house having like intentions.

Something has been done in this direction at public libraries in different parts of the country. At Coventry, for example, the staff of the Central Library invites inquiries for information, whether made personally, or by letter, or by telephone, and lists of original papers and books dealing with particular technical subjects are issued in printed form and circulated widely among manufacturers and others interested in them. The Glasgow libraries are also issuing lists of works on various technical subjects; and the Library Association, in a report referred to last week (p. 257), points out that a national lending library of books suitable for giving assistante in scientific and technological research would be of the greatest advantage to technologists.

At the annual meeting of this association, held at the beginning of October, Dr. Addison, the Minister of Reconstruction, said that one of the NO. 25 IO, VOL. IOO] features of the programme which appealed to him was this movement for the formation of technical and commercial libraries and for the setting up of research libraries to suit the particular needs and industries of various districts. It is, however, not sufficient to provide for local needs; there should also be a central library and bureau which would make the position of knowledge in any scientific or technical subject available to any inquirer. Such an institution could be made self-supporting after a time, for manufacturers would not hesitate to pay fees for information required by them to develop their industries. We look to Dr. Addison and the Advisory Council for Scientific and Industrial Research to provide this centralised means of assisting industrial development.

\section{THE ORDER OF NATURE.}

The Order of Nature. By Prof. L. J. Henderson. Pp. iv +234 . (Cambridge, Mass. : Harvard University Press; London: Humphrey Milford, Oxford University Press, 1917.) Price 6s. 6d. net.

PROF. L. J. HENDERSON, of Harvard, is 1 well known for his important experimental work in bio-chemistry. $\mathrm{He}$ is also the author of a previous book entitled "The Fitness of the Environment," in which the inherent fitness for life of the actual physical and chemical world is pointed out in detail. In the present work he has followed up and developed the same thesis.

The first three chapters, beginning with an analysis of Aristotle's distinction between "final" and "efficient" causes, are devoted to an historical survey of ideas on the teleological appearance, not only of organic structure, but of Nature as a whole, considered as a fitting environment for life. Up to the middle of the nineteenth century the fact of a teleological determination of Nature as a whole was admitted by nearly all leading. thinkers, however variously this fact was explained. The same admission appears in some of Darwin's writings; but since the publication of the theory of natural selection the teleological conception of Nature has almost disappeared from scientific thought. It has come to be assumed that the reason why the physical and chemical environment appears to be specially fitted for life is simply that life has, by natural selection, been so moulded as to fit its environment. Against this conclusion the main chapters of the book are directed; and the argument is the more remarkable and original since the author accepts without question the theory of natural selection. His discussion of Spencer's conception of evolution is perhaps specially luminous.

The reasoning is based entirely on the general. characteristics of life from the point of view of physical chemistry, and particularly from that of Willard Gibbs's analysis of the conditions of stability and variability of physico-chemical systems, living organisms being regarded as such 